\title{
A GC polymorphism associated with serum 25-hydroxyvitamin $D$ level is a risk factor for hip fracture in Japanese patients with rheumatoid arthritis: 10-year follow-up of the Institute of Rheumatology, Rheumatoid Arthritis cohort study
}

Shinji Yoshida ${ }^{1,2+}$, Katsunori Ikari ${ }^{{ }^{* \dagger}}$, Takefumi Furuya ${ }^{1}$, Yoshiaki Toyama ${ }^{2}$, Atsuo Taniguchi ${ }^{1}$, Hisashi Yamanaka ${ }^{1}$ and Shigeki Momohara ${ }^{1}$

\begin{abstract}
Introduction: Vitamin D deficiency has been reported to be common in patients with rheumatoid arthritis (RA) who have a higher prevalence of osteoporosis and hip fracture than healthy individuals. Genetic variants affecting serum 25-hydroxyvitamin D (25(OH)D) concentration, an indicator of vitamin D status, were recently identified by genome-wide association studies of Caucasian populations. The purpose of this study was to validate the association and to test whether the serum 25(OH)D-linked genetic variants were associated with the occurrence of hip fracture in Japanese RA patients.

Methods: DNA samples of 1,957 Japanese RA patients were obtained from the Institute of Rheumatology, Rheumatoid Arthritis (IORRA) cohort DNA collection. First, five single nucleotide polymorphisms (SNPs) that were reported to be associated with serum $25(\mathrm{OH}) \mathrm{D}$ concentration by genome-wide association studies were genotyped. The SNPs that showed a significant association with serum 25(OH)D level in the cross-sectional study were used in the longitudinal analysis of hip fracture risk. The genetic risk for hip fracture was determined by a multivariate Cox proportional hazards model in 1,957 patients with a maximum follow-up of 10 years (median, 8 years).

Results: Multivariate linear regression analyses showed that rs2282679 in GC (the gene encoding group-specific component (vitamin D binding protein)) locus was significantly associated with lower serum 25(OH)D concentration $\left(P=8.1 \times 10^{-5}\right)$. A Cox proportional hazards model indicated that rs 2282679 in GC was significantly associated with the occurrence of hip fracture in a recessive model (hazard ratio ( $95 \%$ confidence interval) $=2.52(1.05-6.05), P=0.039$ ).
\end{abstract}

Conclusions: A two-staged analysis demonstrated that rs2282679 in GC was associated with serum 25(OH)D concentration and could be a risk factor for hip fracture in Japanese RA patients.

\footnotetext{
* Correspondence: kikari@ior.twmu.ac.jp

${ }^{\dagger}$ Equal contributors

${ }^{1}$ Institute of Rheumatology, Tokyo Women's Medical University,

10-22 Kawada, Shinjuku, Tokyo 162-0054, Japan

Full list of author information is available at the end of the article
} 


\section{Introduction}

Vitamin D regulates calcium and phosphate homeostasis and reportedly has other roles in human physiology $[1,2]$. Vitamin D deficiency is associated with the occurrence of osteoporosis, autoimmune diseases, cardiovascular disease, type 1 and type 2 diabetes mellitus, and several types of cancer [3-7]. Vitamin D also plays an important role in the maintenance of the musculoskeletal system. It is positively associated with muscle strength and physical performance, and is negatively associated with fall and fracture risk [8-11].

Vitamin D deficiency has been reported to be common in patients with rheumatoid arthritis (RA), and more than $70 \%$ of Japanese patients with RA had vitamin D deficiency [12,13]. Significant associations of vitamin D deficiency were found with some independent clinical risk factors: female gender, younger age, high disability score in the Japanese version of the Health Assessment Questionnaire (J-HAQ), low serum total protein level, low serum total cholesterol level, high serum alkaline phosphate (ALP) level, and use of non-steroidal antiinflammatory drugs (NSAIDs) [12].

Bone mineral density (BMD) is the major predictor of osteoporotic fracture, and previous studies have reported that patients with RA have a lower BMD and are at greater risk of hip fracture than healthy individuals $[14,15]$. We have previously shown that a high J-HAQ disability score, advanced age, history of total knee replacement (TKR), and low body mass index (BMI) were clinical risk factors for the occurrence of hip fracture in Japanese patients with RA [16].

Prior twin and family studies suggested that genetic factors also influence serum vitamin D concentration $[17,18]$. Genetic variants that affect serum 25-hydroxyvitamin D $(25(\mathrm{OH}) \mathrm{D})$ concentration, an indicator of vitamin D status, were recently identified in a meta-analysis of genome-wide association studies (GWAS) in Caucasian populations $[19,20]$. Though the presence of heterogeneity in genes related to RA has been suggested in many population-based studies [21], these associations remain unknown in the Japanese population.

The purpose of this study was to validate the possible association between genetic variants and serum $25(\mathrm{OH})$ D concentration and to test whether the serum $25(\mathrm{OH})$ D-linked variants were associated with the occurrence of hip fracture in Japanese patients with RA.

\section{Methods}

\section{Study population}

This study was a part of the Institute of Rheumatology, Rheumatoid Arthritis cohort study (IORRA), a singleinstitution-based, large-scale prospective observational cohort study with an enrollment of over 5,000 Japanese patients with RA, began in $2000[12,16,22]$. DNA samples of 1,957 Japanese RA patients were obtained from the IORRA DNA collection. All the patients satisfied the American College of Rheumatology 1987 revised criteria for RA. Tokyo Women's Medical University Genome Ethics Committee approved the present study and each individual signed an informed consent form after receiving a verbal explanation of the study.

\section{SNP selection and genotyping}

Five single nucleotide polymorphisms (SNPs) were selected from the results of recent genome-wide association studies (GWAS) that showed positive associations between serum 25(OH)D levels and the following: rs2282679 in the GC (group-specific component) locus, rs3829251, rs12785878 and rs1790349 in the DHCR7/NADSYN1 (7-dehydrocholesterol reductase/nicotinamide-adenine dinucleotide synthetase 1) locus, and rs10741657 in the CYP2R1 (cytochrome P450, family 2 , subfamily $R$, polypeptide 1) locus $[19,20]$. Genotyping was performed by using the TaqMan fluorogenic 5 ' nuclease assay according to the manufacturer's instructions (Applied Biosystems, Tokyo, Japan). Duplicate samples and negative controls were included to ensure accuracy of SNP genotyping. All polymerase chain reactions were performed by using the GeneAmp PCR System 9700 (Applied Biosystems), and endpoint fluorescent readings for TaqMan assays were done on an ABI PRISM 7900 HT Sequence Detection System (Applied Biosystems) as described elsewhere [22].

\section{Measurement of serum 25(OH)D concentration}

Serum 25(OH)D concentrations were measured in 899 of 1,957 patients from whom we obtained DNA samples. As vitamin $D$ is synthesized in the skin under the influence of sunlight and the seasonal variance in serum levels of vitamin D is well known, serum samples were collected in the same season, spring of 2011 [23]. The DiaSorin $25(\mathrm{OH}) \mathrm{D}^{125}$ I radioimmunoassay kit was used for quantitative determination of serum $25(\mathrm{OH}) \mathrm{D}$ concentration.

\section{Assessment of hip fracture}

The occurrence of hip fracture after enrollment in IORRA was determined by the response to a patient questionnaire every six months from October 2000 to October 2010 with a maximum follow-up period of 10 years. The data were confirmed by review of medical records and radiographs as described elsewhere [16]. Only the occurrence of the first hip fracture reported by patients was included in this study. The occurrence of hip fracture caused by major trauma such as car accidents was excluded. A total of 39 hip fractures in 39 patients were identified and included in this study. 


\section{Statistical analyses}

Stage 1: cross-sectional analyses of SNPs associated with serum 25(OH)D concentration

A two-staged analysis was used. First, cross-sectional associations were examined between serum 25(OH)D concentrations and risk alleles of each SNP using multivariate linear regression analyses (adjusted for independent non-genetic risk factors) in 899 of the 1,957 patients. The putative risk alleles were defined as the alleles that are associated with lower serum $25(\mathrm{OH}) \mathrm{D}$ concentration based on prior reports $[19,20]$. The number of risk alleles for genotyped SNPs (0, 1 and 2) was used to test the additive effect of the alleles on lower serum 25(OH)D concentration. The following factors that have been shown to be significantly associated with lower serum 25(OH)D levels were selected as independent non-genetic risk factors: gender, age, J-HAQ disability score, serum total protein level, serum total cholesterol level, serum ALP level, and NSAID use [12].

\section{Stage 2: longitudinal association analyses of SNPs associated with occurrence of hip fracture}

The SNP that showed a significant association with serum $25(\mathrm{OH}) \mathrm{D}$ concentration was selected to test the longitudinal association with the hip fracture event. The length of time from the date of enrollment in IORRA to the date of the occurrence of hip fracture was calculated. A multivariate Cox proportional hazards model adjusted for independent non-genetic risk factors that were associated with hip fracture was performed in the cohort of 1,957 patients [16]. The following factors at the time of hip fracture reported were used as the independent nongenetic risk factors: J-HAQ disability score, age, history of TKR, and BMI. The proportional hazards assumption for the Cox model was assessed using log-minus-log plots for survival analysis. All statistical analyses were performed using the R software package [24].

\section{Results}

Clinical and demographic characteristics of the patients Demographic, clinical and therapeutic data describing the 1,957 patients at the time of enrollment in IORRA are shown in Table 1 . In this cohort, serum 25(OH)D concentrations were measured in 899 patients in the spring of 2011 (Table 1). The median serum 25(OH)D concentration was $15.30 \mathrm{ng} / \mathrm{mL}$ (IQR, 12.10 to 20.10). During a maximum follow-up period of 10 years (median, 8.0 years; IQR, 4.5 to 10.0 years) 39 hip fractures in 1,957 patients were identified.

\section{Genotyping}

The overall genotyping success rate was $97.3 \%$ and the genotype concordance rate was $100 \%$ as assessed by duplicate samples. After the application of quality control criteria for genotyping (removed samples that consistently failed for $>20 \%(1 / 5)$ of SNPs, removed SNPs with a call rate $<95 \%$ after removing samples that consistently failed), 1,915 of the 1,957 samples and all polymorphisms were accepted for the analyses. The studied polymorphisms were found to be in Hardy-Weinberg equilibrium.

\section{Stage 1: cross-sectional analyses of SNPs associated with serum 25(OH)D concentration}

A multivariate linear regression analysis adjusted for independent non-genetic risk factors showed that the minor allele of rs2282679 (=C) in GC was significantly associated with lower serum $25(\mathrm{OH}) \mathrm{D}$ concentrations $\left(P=8.1 \times 10^{-5}\right.$, Table 2). The median serum 25(OH)D concentrations (ng/mL) for the genotypes of rs2282679 in GC were 16.1, 15.2 and 14.7, respectively for AA, AC and CC (Figure 1). The other SNPs did not show a significant association. The minor allele frequency of rs2282679 (GC) in RA patients $(=0.259)$ did not differ significantly from a Japanese control population $(=0.258, P=0.98$ by chi-squared test, $\mathrm{n}=752$ ), which was obtained from the DNA collection of the Pharma SNP Consortium, Tokyo, Japan, currently entrusted to the Health Science Research Resources Bank, Osaka, Japan, as described elsewhere [22].

\section{Stage 2: longitudinal association analyses of SNPs associated with occurrence of hip fracture}

A multivariate Cox proportional hazards regression model adjusted for the independent non-genetic risk factors indicated that homozygous for the risk allele of rs2282679 in the GC locus regarding low serum $25(\mathrm{OH})$ $\mathrm{D}$ concentration was significantly associated with the occurrence of hip fracture (hazard ratio $(95 \% \mathrm{CI})=2.52$ (1.05, 6.05), $P=0.039)$ (Table 3 , Figure 2). The association was still significant when the use of active vitamin $\mathrm{D}$ or bisphosphonate were included in the analysis as independent variables. The proportion of patients treated with active vitamin $\mathrm{D}$ or bisphosphonate did not differ significantly between homozygous for the risk allele of rs2282679 (CC) and the others (data not shown). Supplemental results of the Cox regression analyses for other SNPs that were not associated with serum $25(\mathrm{OH})$ $\mathrm{D}$ concentration did not show a significant association with the occurrence of hip fracture (Table 3, Figure 2).

\section{Discussion}

In this study, an association between a polymorphism of rs2282679 in the GC locus and serum 25(OH)D concentration was validated in Japanese patients with RA. Minor alleles of rs2282679 had additive effects on decreasing serum $25(\mathrm{OH}) \mathrm{D}$ concentrations. In addition, rs2282679 was significantly associated with the occurrence of hip fracture in Japanese patients with RA. This 
Table 1 Demographic, clinical and therapeutic data at the time of an enrollment in IORRA and at the time of measurement of serum 25(OH)D concentration

\begin{tabular}{|c|c|c|}
\hline Factor & At the time of enrollment in IORRA $(n=1957)$ & $\begin{array}{l}\text { At the time of measurement of serum } \\
25(\mathrm{OH}) \mathrm{D} \text { concentration (spring 2011, } \mathrm{n}=899 \text { ) }\end{array}$ \\
\hline Age, years & 57.5 (49.5 to 64.6$)$ & $64.3(56.7$ to 70.6$)$ \\
\hline Sex, female & $1668(85.2)$ & $766(87.7)$ \\
\hline Duration of disease, years & $7.0(2.0$ to 14.0$)$ & $16.0(11.0$ to 23.0$)$ \\
\hline $\mathrm{BMI}, \mathrm{kg} / \mathrm{m}^{2}$ & $21.2(19.4$ to 23.3$)$ & 21.2 (19.2 to 23.2 ) \\
\hline DAS28 & $4.2(3.3$ to 5.0$)$ & $3.0(2.4$ to 3.8$)$ \\
\hline J-HAQ & $0.8(0.2$ to 1.4$)$ & $0.6(0.1$ to 0.8$)$ \\
\hline RF, positive & $1531(81.8)$ & $698(80.0)$ \\
\hline History of smoking, ever & $641(34.5)$ & $235(28.4)$ \\
\hline History of TKR, ever & $85(4.3)$ & $178(20.4)$ \\
\hline DMARDs use, ever & $1670(85.3)$ & $777(89.0)$ \\
\hline Methotrexate use, ever & $792(40.8)$ & $638(73.1)$ \\
\hline Biologic use, ever & $12(0.6)$ & $155(17.8)$ \\
\hline Corticosteroid use, ever & $932(47.6)$ & $399(45.7)$ \\
\hline Bisphosphonate use, ever & $63(3.2)$ & $280(32.1)$ \\
\hline Active vitamin D use, ever & $61(3.1)$ & $112(12.8)$ \\
\hline Serum total protein level, g/dL & Data not available & 7.3 (7.0 to 7.6$)$ \\
\hline Serum total cholesterol level, mg/dL & Data not available & 209.0 (188.0 to 231.0) \\
\hline Serum alkaline phosphate level, IU/L & Data not available & 258.0 (213.0 to 321.2) \\
\hline NSAIDs use, ever & Data not available & $515(59.0)$ \\
\hline
\end{tabular}

Data are presented as median (IQR) or $\mathrm{n}(\%)$. IORRA, Institute of Rheumatology, Rheumatoid Arthritis cohort; BMI, body mass index; DAS28, disease activity score in 28 joints; J-HAQ, Japanese version of the Health Assessment Questionnaire; RF, rheumatoid factor; TKR, total knee replacement; DMARD, disease modifying antirheumatic drug; NSAID, non-steroidal anti-inflammatory drug.

is the first report that a SNP P7 in the GC locus was associated with the risk for hip fracture.

The GC gene encodes the group-specific component known as the vitamin D binding protein (DBP) that plays an important role in the vitamin $\mathrm{D}$ metabolic pathway [25]. Most circulating vitamin D metabolites are bound to DBP to be transported to target organs. In the previous candidate gene studies and the recent GWAS, some GC polymorphisms were associated with serum $25(\mathrm{OH}) \mathrm{D}$ concentration, and the strongest association was observed for rs2282679 [19,20,26]. Our results provide supportive evidence that serum $25(\mathrm{OH}) \mathrm{D}$ concentration might partly be affected by a polymorphism of rs2282679 or the other variants that are in tight linkage disequilibrium with rs2282679.

Vitamin D is an important factor in mineral metabolism, bone growth and maintenance of the skeleton [1]. In addition, $1,25(\mathrm{OH})_{2} \mathrm{D}$, one of the vitamin $\mathrm{D}$ metabolites, has direct action on muscle strength and function modulated by vitamin $\mathrm{D}$ receptors expressed in human muscle tissue [8]. Therefore, vitamin D deficiency can lead to low bone density and muscle weakness, resulting in falls and fractures $[8,27,28]$. In many studies, vitamin
D supplementation has been reported to reduce the risk for falls and fractures among older individuals $[29,30]$.

To date, many genetic factors associated with lowtrauma fracture including hip fracture have been reported in genome-wide meta-analysis studies [31,32]. Many variants with small effects may contribute to fracture risk, but only a few vitamin D-related genetic polymorphisms

Table 2 Multivariate linear regression analyses of each SNP associated with serum 25(OH)D concentration

\begin{tabular}{llllll}
\hline Locus & SNP & MAF $^{\dagger}$ & $\boldsymbol{\beta}$ & SE & $\boldsymbol{P}$-value \\
\hline GC & rs2282679 & $0.259(\mathrm{~A} / \mathrm{C})$ & -0.13 & 0.033 & $8.1 \times 10^{-5}$ \\
DHCR7/NADSYN1 & rs3829251 & $0.375(\mathrm{G} / \mathrm{A})$ & -0.0031 & 0.032 & 0.92 \\
& $\mathrm{rs} 12785878$ & $0.328(\mathrm{G} / \mathrm{T})$ & 0.0057 & 0.032 & 0.86 \\
& $\mathrm{rs} 1790349$ & $0.361(\mathrm{~A} / \mathrm{G})$ & -0.016 & 0.032 & 0.63 \\
CYP2R1 & rs10741657 & $0.387(\mathrm{G} / \mathrm{A})$ & 0.035 & 0.034 & 0.30 \\
\hline
\end{tabular}

All analyses were adjusted for independent non-genetic risk factors: gender, age, Japanese version of the Health Assessment Questionnaire disability score, total protein level, total cholesterol level, alkaline phosphate level, and non-steroidal anti-inflammatory drugs use [12]. ${ }^{\dagger}$ Alleles are listed as major allele/minor allele. SNP, single nucleotide polymorphism; MAF, minor allele frequency; SE, standard error; GC, group-specific component; DHCR7/NADSYN1, 7-dehydrocholesterol reductase/nicotinamide-adenine dinucleotide synthetase 1; CYP2R1, cytochrome P450, family 2, subfamily R, polypeptide 1 . 


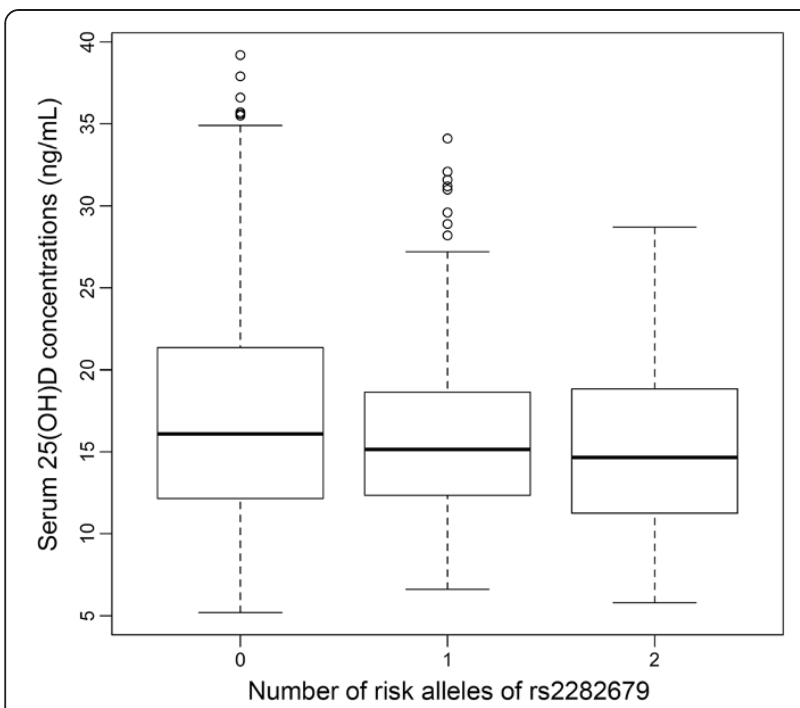

Figure 1 Boxplots representing the distribution of serum 25 $(\mathrm{OH}) \mathrm{D}$ concentration according to the number of the risk allele of rs2282679 (minor allele, C) in the GC locus. Each box represents the IQR range of values, with the bold line showing the median value. The vertical lines show maximum and minimum values that fall within 1.5 box lengths, the open circles show extreme values $>1.5$ box plot lengths.

have been reported to be associated with fracture risk [33]. We explored the genetic risk of hip fracture in variants demonstrated to be associated with lower serum vitamin $\mathrm{D}$ concentration and found an association between rs2282679 in GC and the occurrence of hip fracture. Our results indicated that the risk allele carriers of the $G C$ gene polymorphism tend to have low vitamin $D$ levels that lead to greater risk of hip fracture.

Though DHCR7/NADSYN1 and CYP2R1 polymorphisms were associated with serum 25(OH)D

Table 3 Hip fracture risk for rs2282679 (GC) and the other SNPs adjusted for independent non-genetic risk factors

\begin{tabular}{lllll}
\hline Locus & SNP & HR & 95\% Cl & $P$-value \\
\hline GC & rs2282679 & 2.52 & $1.05,6.05$ & 0.039 \\
DHCR7/NADSYN1 & rs3829251 & 1.00 & $0.39,2.56$ & 1.00 \\
& rs12785878 & 0.71 & $0.22,2.30$ & 0.56 \\
& rs1790349 & 1.04 & $0.40,2.65$ & 0.94 \\
CYP2R1 & rs10741657 & 1.31 & $0.58,3.02$ & 0.51 \\
\hline
\end{tabular}

All analyses were adjusted for independent non-genetic factors: Japanese version of the Health Assessment Questionnaire disability score, age, history of total knee replacement, and body mass index [16]. SNP, single nucleotide polymorphism; HR, hazard ratio; GC, group-specific component; DHCR7/NADSYN1, 7-dehydrocholesterol reductase/nicotinamide-adenine dinucleotide synthetase 1 ; CYP2R1, cytochrome P450, family 2 , subfamily $\mathrm{R}$, polypeptide 1 . concentration in the recent GWAS, we could not validate such an association in this study $[19,20]$. There are a number of possible explanations for the lack of an association. One is the insufficient statistical power to validate the associations. The number of samples was smaller than in the previous reports [20]. The SNP with highest statistical power to validate the association in this study was rs2282679 in the $G C$ locus with a value of 0.72 , and the others had comparatively lower statistical power (for example, 0.22 with rs3829251 in the DHCR7/NADSYN1 locus). Another reason for the lack of an association is that all studied subjects were RA patients, whereas the recent GWAS were in healthy individuals $[19,20]$. Vitamin D is related to immunological processes, and vitamin D status has been reported to be associated with the risk of developing autoimmune diseases including RA [1,14]. In addition, serum vitamin $\mathrm{D}$ concentration has been shown to be lower in patients with greater disease activity [34]. Although the disease activity of the patients might affect the results of this study, DAS28 was not associated with serum 25(OH)D level in the studied population (data not shown). The difference in the genetic background between Caucasian and Japanese populations might also affect the results, which suggests genetic heterogeneity in NADSYN1, DHCR7 and CYP2R1.

The strength of this study is that the datasets were relatively large and based on a single-institution cohort study of Japanese patients with RA. Serum 25(OH)D concentration was measured in the same season of the same year. Therefore, the differences between regions, heterogeneity and seasons had less influence on the results.

The potential limitation of this study is that the serum 25(OH)D concentration data were available from only 899 of the 1,957 patients with DNA samples, and the study on serum $25(\mathrm{OH}) \mathrm{D}$ concentration was a cross-sectional study. The smaller sample size reduced the statistical power to detect minor effects on events. Though the measurement from multiple time points would provide more valid estimates of the results, there was only one blood sample assayed for serum 25 $(\mathrm{OH}) \mathrm{D}$ concentration for each person. Further studies are required to confirm these associations.

\section{Conclusion}

In conclusion, our data demonstrated that rs 2282679 in $G C$ was associated with both serum $25(\mathrm{OH}) \mathrm{D}$ concentration and the occurrence of hip fracture in Japanese patients with RA. These results might contribute to a better understanding of the biological impact of genetic variation within the vitamin D metabolic pathway. 

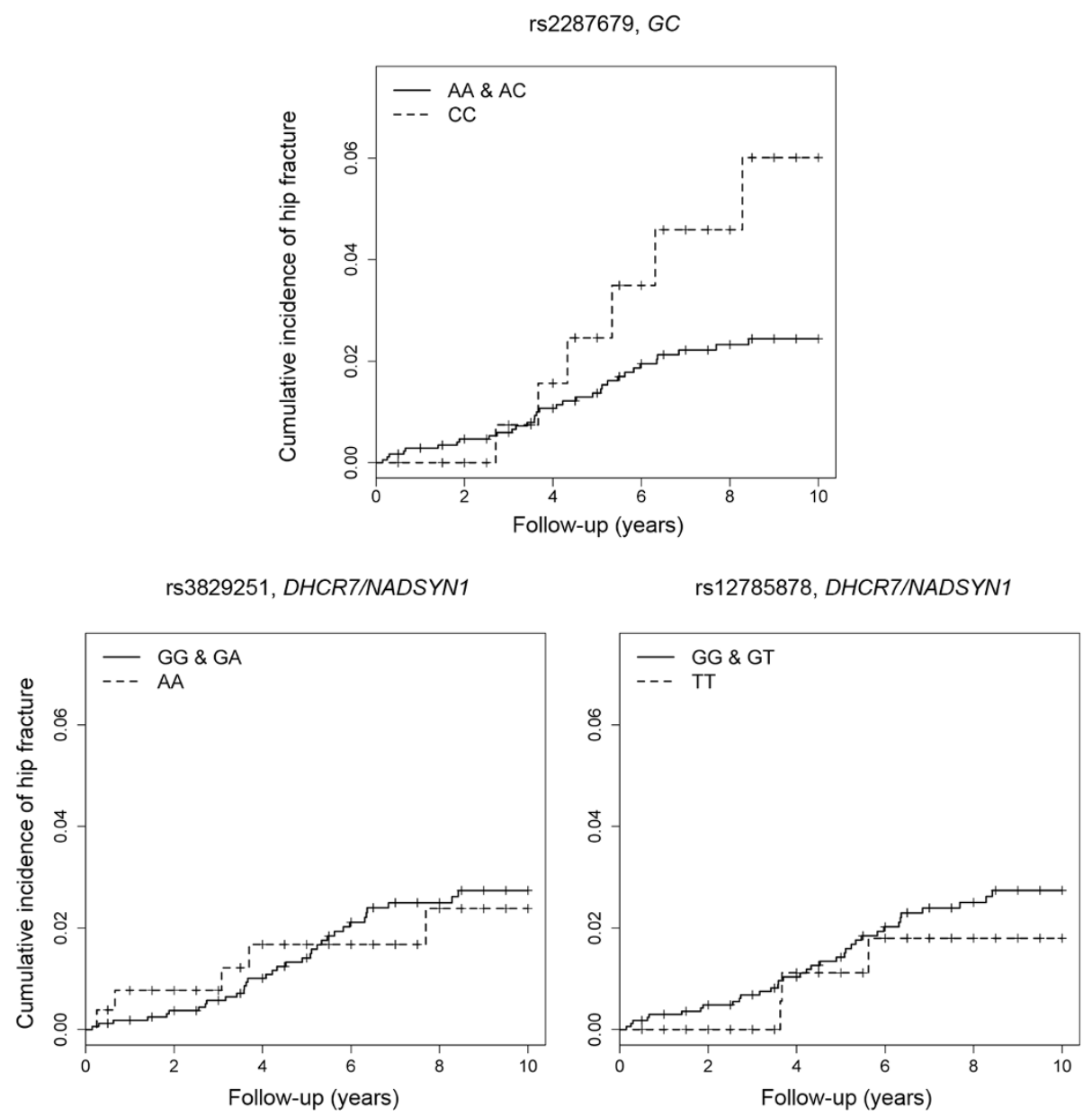

rs1790349, DHCR7/NADSYN1
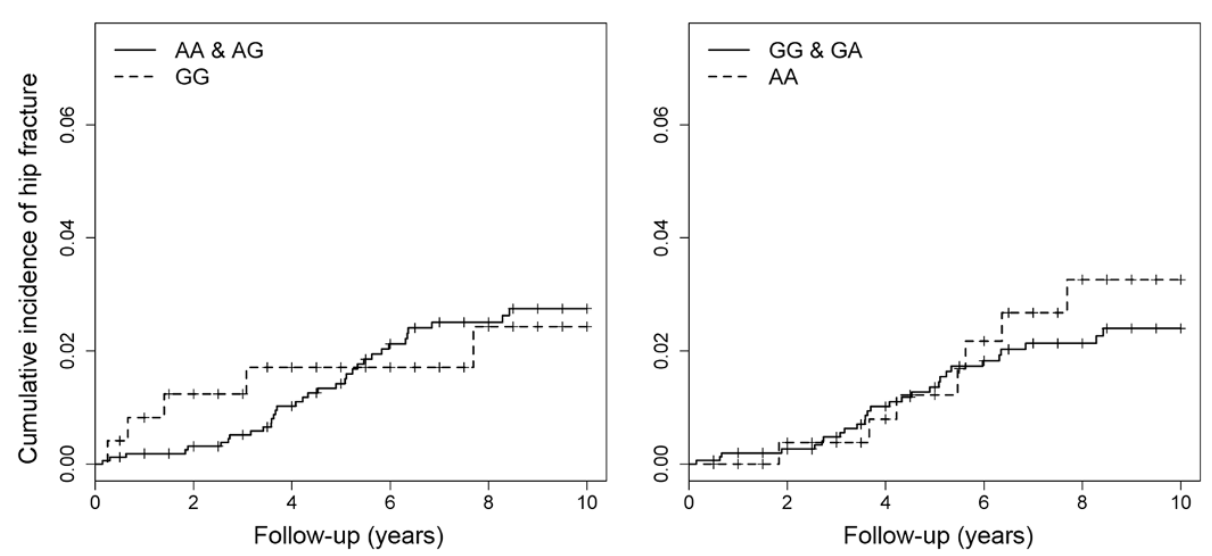

Figure 2 Cumulative incidence of hip fracture for patients who were homozygous or heterozygous for the non-risk allele and patients homozygous for the risk allele of each single nucleotide polymorphism (analyzed by the Kaplan-Meier method). Homozygous for the risk allele of rs2282679 (C) in the GC locus, a serum 25(OH)D-linked genetic variant, was significantly associated with the occurrence of hip fracture. 


\section{Abbreviations}

25(OH)D: 25-hydroxyvitamin D; ALP: Alkaline phosphatase; BMD: bone mineral density; BMI: body mass index; CYP2R1: Cytochrome P450, family 2, subfamily R, polypeptide 1; DAS28: disease activity score in 28 joints: DBP: Vitamin D binding protein; DHCR7/NADSYN1: 7-dehydrocholesterol reductase/nicotinamide-adenine dinucleotide synthetase 1; DMARD: Disease modifying antirheumatic drug; GC: Group-specific component; GWAS: Genome-wide association studies; IORRA: Institute of Rheumatology, Rheumatoid Arthritis; IQR: inter-quartile range; J-HAQ: Japanese version of the Health Assessment Questionnaire; MAF: minor allele frequency; NSAID: non-steroidal anti-inflammatory drug; RA: rheumatoid arthritis; RF: rheumatoid factor; SE: standard error; SNP: single nucleotide polymorphism; TKR: total knee replacement.

\section{Competing interests}

The authors declared that they have no competing interests.

\section{Authors' contributions}

$\mathrm{KI}$ designed the study. KI, TF, YT, AT, HY and SM collected DNA samples and the data on fracture. SY and KI performed genotyping. SY and KI contributed to the statistical analyses. SY and KI wrote most of the manuscript. All authors contributed to writing and correcting the manuscript and have approved the final version.

\section{Acknowledgements}

We appreciate all DNA donors for making this study possible. We thank all members of the Institute of Rheumatology, Tokyo Women's Medical University for their successful management of the IORRA cohort. We are also grateful to Ms Kaori Arai and Ms Akiko Sato for their technical assistance and to Dr Eisuke Inoue for his guidance and suggestions in statistical analyses. This work was supported by grants provided by the Japanese Ministry of Education, Culture, Sports, Science and Technology Grant-in-Aid for Scientific Research (KI, SM), the Japanese Ministry of Health, Labour and Welfare $(\mathrm{SM}, \mathrm{HY})$ and the Japan Science and Technology Agency (HY)

\section{Author details}

${ }^{1}$ Institute of Rheumatology, Tokyo Women's Medical University, 10-22 Kawada, Shinjuku, Tokyo 162-0054, Japan. ${ }^{2}$ Department of Orthopaedic Surgery, Keio University School of Medicine,

35 Shinano, Shinjuku, Tokyo 160-8582, Japan.

Received: 9 December 2013 Accepted: 13 March 2014

Published: 20 March 2014

\section{References}

1. DeLuca HF: Overview of general physiologic features and functions of vitamin D. Am J Clin Nutr 2004, 80:1689S-1696S

2. Anderson $\mathrm{PH}$, Turner $\mathrm{AG}$, Morris $\mathrm{HA}$ : Vitamin $\mathrm{D}$ actions to regulate calcium and skeletal homeostasis. Clin Biochem 2012, 45:880-886.

3. Pludowski $P$, Holick MF, Pilz S, Wagner CL, Hollis BW, Grant WB, Shoenfeld Y, Lerchbaum E, Llewellyn DJ, Kienreich K, Soni M: Vitamin D effects on musculoskeletal health, immunity, autoimmunity, cardiovascular disease, cancer, fertility, pregnancy, dementia and mortality-a review of recent evidence. Autoimmun Rev 2013, 12:976-989.

4. Shui IM, Mucci LA, Kraft P, Tamimi RM, Lindstrom S, Penney KL, Nimptsch K, Hollis BW, Dupre N, Platz EA, Stampfer MJ, Giovannucci E: Vitamin Drelated genetic variation, plasma vitamin $D$, and risk of lethal prostate cancer: a prospective nested case-control study. J Natl Cancer Inst 2012, 104:690-699.

5. Ritterhouse LL, Crowe SR, Niewold TB, Kamen DL, Macwana SR, Roberts VC, Dedeke AB, Harley JB, Scofield RH, Guthridge JM, James JA: Vitamin D deficiency is associated with an increased autoimmune response in healthy individuals and in patients with systemic lupus erythematosus. Ann Rheum Dis 2011, 70:1569-1574

6. Gennari C: Calcium and vitamin D nutrition and bone disease of the elderly. Public Health Nutr 2001, 4:547-559.

7. Bhan A, Rao AD, Rao DS: Osteomalacia as a result of vitamin D deficiency. Endocrinol Metab Clin North Am 2010, 39:321-331.

8. Ceglia L, Harris SS: Vitamin D and its role in skeletal muscle. Calcif Tissue Int 2013, 92:151-162.
9. Orstavik RE, Haugeberg G, Uhlig T, Mowinckel P, Falch JA, Halse JI, Kvien TK Self reported non-vertebral fractures in rheumatoid arthritis and population based controls: incidence and relationship with bone mineral density and clinical variables. Ann Rheum Dis 2004, 63:177-182.

10. van Staa TP, Geusens P, Bijlsma JW, Leufkens HG, Cooper C: Clinical assessment of the long-term risk of fracture in patients with rheumatoid arthritis. Arthritis Rheum 2006, 54:3104-3112.

11. Armstrong C, Swarbrick CM, Pye SR, O'Neill TW: Occurrence and risk factors for falls in rheumatoid arthritis. Ann Rheum Dis 2005, 64:1602-1604.

12. Furuya T, Hosoi T, Tanaka E, Nakajima A, Taniguchi A, Momohara S, Yamanaka $\mathrm{H}$ : Prevalence of and factors associated with vitamin D deficiency in 4,793 Japanese patients with rheumatoid arthritis. Clin Rheumatol 2013, 32:1081-1087.

13. Bischoff-Ferrari HA, Giovannucci E, Willett WC, Dietrich T, Dawson-Hughes B: Estimation of optimal serum concentrations of 25-hydroxyvitamin $D$ for multiple health outcomes. Am J Clin Nutr 2006, 84:18-28.

14. Rossini M, Maddali Bongi S, La Montagna G, Minisola G, Malavolta N, Bernini L, Cacace E, Sinigaglia L, Di Munno O, Adami S: Vitamin D deficiency in rheumatoid arthritis: prevalence, determinants and associations with disease activity and disability. Arthritis Res Ther 2010, 12:R216.

15. Kim SY, Schneeweiss S, Liu J, Daniel GW, Chang CL, Garneau K, Solomon DH: Risk of osteoporotic fracture in a large population-based cohort of patients with rheumatoid arthritis. Arthritis Res Ther 2010, 12:R154.

16. Furuya T, Inoue E, Hosoi T, Taniguchi A, Momohara S, Yamanaka H: Risk factors associated with the occurrence of hip fracture in Japanese patients with rheumatoid arthritis: a prospective observational cohort study. Osteoporos Int 2013, 24:1257-1265.

17. Shea MK, Benjamin EJ, Dupuis J, Massaro JM, Jacques PF, D'Agostino RB Sr Ordovas JM, O'Donnell CJ, Dawson-Hughes B, Vasan RS, Booth SL: Genetic and non-genetic correlates of vitamins K and D. Eur J Clin Nutr 2009, 63:458-464.

18. Hunter D, De Lange M, Snieder H, MacGregor AJ, Swaminathan R, Thakker RV, Spector TD: Genetic contribution to bone metabolism, calcium excretion, and vitamin D and parathyroid hormone regulation. J Bone Miner Res 2001, $16: 371-378$

19. Wang TJ, Zhang F, Richards JB, Kestenbaum B, van Meurs JB, Berry D, Kiel DP, Streeten EA, Ohlsson C, Koller DL, Peltonen L, Cooper JD, O'Reilly PF, Houston DK, Glazer NL, Vandenput L, Peacock M, Shi J, Rivadeneira F, McCarthy MI, Anneli P, de Boer IH, Mangino M, Kato B, Smyth DJ, Booth SL, Jacques PF, Burke GL, Goodarzi M, Cheung CL, et al: Common genetic determinants of vitamin $D$ insufficiency: a genome-wide association study. Lancet 2010, 376:180-188.

20. Ahn J, Yu K, Stolzenberg-Solomon R, Simon KC, McCullough ML, Gallicchio L, Jacobs EJ, Ascherio A, Helzlsouer K, Jacobs KB, Li Q, Weinstein SJ, Purdue M, Virtamo J, Horst R, Wheeler W, Chanock S, Hunter DJ, Hayes RB, Kraft P, Albanes D: Genome-wide association study of circulating vitamin D levels. Hum Mol Genet 2010, 19:2739-2745.

21. Okada Y, Terao C, Ikari K, Kochi Y, Ohmura K, Suzuki A, Kawaguchi T, Stahl EA, Kurreeman FA, Nishida N, Ohmiya H, Myouzen K, Takahashi M, Sawada T, Nishioka Y, Yukioka M, Matsubara T, Wakitani S, Teshima R, Tohma S, Takasugi K, Shimada K, Murasawa A, Honjo S, Matsuo K, Tanaka H, Tajima K, Suzuki T, Iwamoto T, Kawamura Y, et al: Meta-analysis identifies nine new loci associated with rheumatoid arthritis in the Japanese population. Nat Genet 2012, 44:511-516.

22. Kobayashi S, Ikari K, Kaneko H, Kochi Y, Yamamoto K, Shimane K, Nakamura Y, Toyama Y, Mochizuki T, Tsukahara S, Kawaguchi Y, Terai C, Hara M, Tomatsu T, Yamanaka H, Horiuchi T, Tao K, Yasutomo K, Hamada D, Yasui N, Inoue H, Itakura M, Okamoto H, Kamatani N, Momohara S: Association of STAT4 with susceptibility to rheumatoid arthritis and systemic lupus erythematosus in the Japanese population. Arthritis Rheum 2008, 58:1940-1946.

23. Kasahara AK, Singh RJ, Noymer A: Vitamin D (25OHD) Serum seasonality in the United States. PLoS One 2013, 8:e65785.

24. R: A language and environment for statistical computing. 2010 [http:// www.r-project.org/]

25. Speeckaert M, Huang G, Delanghe JR, Taes YE: Biological and clinical aspects of the vitamin D binding protein (Gc-globulin) and its polymorphism. Clin Chim Acta 2006, 372:33-42.

26. Ahn J, Albanes D, Berndt SI, Peters U, Chatterjee N, Freedman ND, Abnet CC, Huang WY, Kibel AS, Crawford ED, Weinstein SJ, Chanock SJ, Schatzkin A, Hayes RB: Vitamin D-related genes, serum vitamin D concentrations and prostate cancer risk. Carcinogenesis 2009, 30:769-776. 
27. Jones G: Pharmacokinetics of vitamin D toxicity. Am J Clin Nutr 2008, 88:582S-586S

28. de Koning L, Henne D, Hemmelgarn BR, Woods P, Naugler C: Non-linear relationship between serum 25-hydroxyvitamin $\mathrm{D}$ concentration and subsequent hip fracture. Osteoporos Int 2013, 24:2061-2065.

29. Bischoff-Ferrari HA, Willett WC, Wong JB, Giovannucci E, Dietrich T, DawsonHughes B: Fracture prevention with vitamin D supplementation: a metaanalysis of randomized controlled trials. JAMA 2005, 293:2257-2264.

30. Bischoff-Ferrari HA, Dawson-Hughes B, Staehelin HB, Orav JE, Stuck AE, Theiler R, Wong JB, Egli A, Kiel DP, Henschkowski J: Fall prevention with supplemental and active forms of vitamin D: a meta-analysis of randomised controlled trials. BMJ 2009, 339:b3692.

31. Estrada K, Styrkarsdottir U, Evangelou E, Hsu YH, Duncan EL, Ntzani EE, Oei L, Albagha OM, Amin N, Kemp JP, Koller DL, Li G, Liu CT, Minster RL, Moayyeri A, Vandenput L, Willner D, Xiao SM, Yerges-Armstrong LM, Zheng HF, Alonso N, Eriksson J, Kammerer CM, Kaptoge SK, Leo PJ, Thorleifsson G, Wilson SG, Wilson JF, Aalto V, Alen M, et al: Genome-wide meta-analysis identifies 56 bone mineral density loci and reveals 14 loci associated with risk of fracture. Nat Genet 2012, 44:491-501.

32. Styrkarsdottir U, Halldorsson BV, Gretarsdottir S, Gudbjartsson DF, Walters GB, Ingvarsson $T$, Jonsdottir T, Saemundsdottir J, Center JR, Nguyen TV, Bagger $Y$, Gulcher JR, Eisman JA, Christiansen C, Sigurdsson G, Kong A, Thorsteinsdottir U, Stefansson K: Multiple genetic loci for bone mineral density and fractures. N Engl J Med 2008, 358:2355-2365.

33. Levin GP, Robinson-Cohen C, de Boer IH, Houston DK, Lohman K, Liu Y, Kritchevsky SB, Cauley JA, Tanaka T, Ferrucci L, Bandinelli S, Patel KV, Hagstrom E, Michaelsson K, Melhus H, Wang T, Wolf M, Psaty BM, Siscovick D, Kestenbaum B: Genetic variants and associations of 25-hydroxyvitamin D concentrations with major clinical outcomes. JAMA 2012, 308:1898-1905.

34. Kerr GS, Sabahi I, Richards JS, Caplan L, Cannon GW, Reimold A, Thiele GM, Johnson D, Mikuls TR: Prevalence of vitamin D insufficiency/deficiency in rheumatoid arthritis and associations with disease severity and activity. J Rheumatol 2011, 38:53-59.

\section{doi:10.1186/ar4516}

Cite this article as: Yoshida et al:: A GC polymorphism associated with serum 25 -hydroxyvitamin $D$ level is a risk factor for hip fracture in Japanese patients with rheumatoid arthritis: 10-year follow-up of the Institute of Rheumatology, Rheumatoid Arthritis cohort study. Arthritis Research \& Therapy 2014 16:R75.

\section{Submit your next manuscript to BioMed Central and take full advantage of:}

- Convenient online submission

- Thorough peer review

- No space constraints or color figure charges

- Immediate publication on acceptance

- Inclusion in PubMed, CAS, Scopus and Google Scholar

- Research which is freely available for redistribution 